\title{
Chlorophyllase distribution in ten classes of phytoplankton: a problem for chlorophyll analysis
}

\author{
S. W. Jeffrey \& G. M. Hallegraeff \\ CSIRO Marine Laboratories, Division of Fisheries Research, GPO Box 1538, Hobart, Tasmania 7001, Australia
}

\begin{abstract}
Chlorophyllase activity, which degrades chlorophyll $a$ to chlorophyllide $a$, was investigated in 93 species (113 isolates) of unicellular algae from 10 classes. Chlorophyllide a formation was measured by a simple incubation test in $50 \%$ acetone, followed by chromatography and phase separation techniques. High activity of the acetone-activated chlorophyllase was found in one third of the 68 diatom isolates tested. These included the pennate diatoms Asterionella glacialis, Cylindrotheca fusiformis, Delphineis sp., Grammatophora oceanica, Navicula sp., Nitzschia (2 spp.), Phaeodactylum tricornutum and Thalassionema nitzschioides, and the important bloom-forming centric diatoms Chaetoceros (5 spp.), Detonula pumila, Ditylum brightwellii, Eucampia zodiacus, Lithodesmium undulatum, Skeletonema costatum, Stephanopyxis turris and Streptotheca tamesis. High activity was also found in 2 out of 3 chrysophyte isolates and 2 out of 7 chlorophyte isolates. In contrast, representatives of 7 other classes showed zero or low activity: dinoflagellates (11 isolates), most prymnesiophytes ( 9 isolates), cryptophytes (5 isolates), prasinophytes (4 isolates), chloromonads (2 isolates), 1 rhodophyte and 2 cyanophytes. Significant strain-specific differences in chlorophyllase activity in 6 out of 13 diatom species, 1 chrysophyte, 1 prymnesiophyte and 1 chlorophyte were also observed. A serious problem for chlorophyll analysis is that chlorophyllase can be activated by harvesting techniques before extraction takes place. Filtration causes the most extensive conversion of chlorophyll $a$ to chlorophyllide $a$, particularly in old cultures, but harvesting by centrifugation also causes chlorophyllide formation in some species. The effects are more pronounced in diatoms than other algal groups. The further degradation of chlorophyllide a to pheophorbide a was seldom encountered. While spectrophotometric and fluorimetric methods would not be seriously affected by chlorophyllase activity (provided pheophorbide $a$ is a minor end product). TLC and HPLC techniques for chlorophylls may be rendered invalid due to artefact formation.
\end{abstract}

\section{INTRODUCTION}

An active chlorophyllase (chlorophyll-chlorophyllide-hydrolase, EC 3.1.1.14) occurs in some species of unicellular marine algae (Barrett \& Jeffrey 1964, 1971, Suzuki \& Fujita 1986). Chlorophyllide $a$, the hydrolysis product of chlorophyll $a$, has also been reported from phytoplankton field samples (Patterson \& Parsons 1963, Jeffrey 1965, 1974, Saijo \& Kamiya 1973, Gieskes \& Kraay 1980, Hallegraeff 1981, Gowen et al. 1983). Some of these studies claimed that as much as $50 \%$ of the total chlorophyll a could be in this altered form. Chlorophyllase in vivo catalyses 3 types of reactions: hydrolysis of chlorophyll a to give phytol and chlorophyllide; transesterification; and under certain conditions, synthesis of chlorophyll a from chlorophyllide a and phytol (Beale 1984). Chlorophylls $a$ and $b$ and pheophytins $a$ and $b$ are all sub- strates for chlorophyllase (Holden 1963) forming the corresponding chlorophyllides and pheophorbides respectively. Chlorophyllase is a thylakoid-bound enzyme and in higher plants is thought to be primarily involved in chlorophyll catabolism (Beale 1984). Apparently the enzyme only catalyses chlorophyll breakdown when the disintegration of cell and chloroplast structures makes chlorophyll accessible to the thylakoid-bound enzyme (Holden 1961, Terpstra 1976).

Chlorophyllase is unusually active in aqueous organic solvent mixtures, and simple assays are usually carried out by incubation in 40 to $50 \%$ aqueous solvents, which give maximum activity (Barrett \& Jeffrey 1964, 1971). The chlorophyllide a formed from chlorophyll a can readily be separated from the parent compound by thin-layer chromatography (TLC) (Barrett \& Jeffrey 1971), high-performance liquid chromatography (HPLC) (Mantoura \& Llewellyn 1983) 
or solvent partition techniques (McFeeters et al. 1971, Terpstra \& Goedheer 1975). Recently Suzuki \& Fujita (1986) found pheophorbide $a$ was a major end product of chlorophyllase activity in Skeletonema costatum cultures.

Chlorophyllase is active to a small extent even in $90 \%$ acetone (Barrett \& Jeffrey 1964), the recommended solvent for phytoplankton pigment analysis (SCOR-UNESCO 1966, Strickland \& Parsons 1972, Parsons et al. 1984). To avoid extraction artefacts by inhibiting chlorophyllase activity, Jeffrey (1974) recommended that phytoplankton pigments be extracted in $100 \%$ acetone. This is especially important when pigments are subsequently analysed by TLC or HPLC techniques, since the ratio of accurately determined chlorophylls and degradation products can be used as important physiological and ecological markers (e.g. Jeffrey 1974, Shuman \& Lorenzen 1975 , Hallegraeff 1981). The presence of chlorophyllide $a$ in phytoplankton field samples as evidenced by chromatography may be an indication of senescent diatoms (Jeffrey 1974), an idea that is supported by the finding of significant concentrations of chlorophyllide $a$ on chromatograms of phytoplankton taken during spring diatom blooms in Australian waters (Jeffrey 1974, Hallegraeff 1981).

These problems associated with chlorophyllase prompted further investigations of the extent of chlorophyllase distribution in phytoplankton, and of artefact formation during sample preparation. Ninetythree species (113 isolates) of cultured microalgae from 10 classes were surveyed. The activity of the enzyme was monitored in all species as the hydrolysis product of chlorophyll a (although in green algae chlorophyllide $b$ would also have been formed). The active enzyme was present mainly in diatoms, but was randomly distributed among representatives of other algal classes. Tests of harvesting procedures (e.g. centrifugation and gentle filtration) have also shown that chlorophyllase in certain species can be activated by the harvesting procedures even before solvent extraction takes place. Both young and old cultures are affected by filtration and centrifugation, although old cultures are more susceptible.

\section{MATERIALS AND METHODS}

Algal cultures. Algae were grown in stationary $250 \mathrm{ml}$ Erlenmeyer flasks at $18^{\circ} \mathrm{C}$ under 40 to $60 \mu \mathrm{E}$ $\mathrm{m}^{-2} \mathrm{~s}^{-1}$ white fluorescent light and $12 \cdot 12 \mathrm{~h}$ light: dark cycles. Media were as designated in Jeffrey (1980) which included various dilutions of medium $f$ (Guillard \& Ryther 1962), medium G (Loeblich \& Smith 1968) and for freshwater algae, medium MBL/MB2
(Guillard's medium in Nichols 1973). Algae were harvested during log phase growth (5 to $10 \mathrm{~d}$ ). 'Old' cultures were harvested in stationary phase after $5 \mathrm{wk}$. Except for 15 species studied at the Scripps Institution of Oceanography, California, USA, all other species came from the CSIRO Algal Culture Collection (Jeffrey 1980). A total of 88 marine and 5 freshwater species were examined, which included more than one strain of 16 species (a total of 113 isolates; Table 1). Previous

Table 1. Number of species and total isolates (by class) examined. (Includes for completeness species previously examined by Barrett \& Jeffrey 1964, 1971)

\begin{tabular}{|lccc|}
\hline \multicolumn{1}{|c}{ Algal class } & Species & $\begin{array}{c}\text { Total } \\
\text { isolates }\end{array}$ & $\begin{array}{c}\text { Species with } \\
\text { 2 or more strains }\end{array}$ \\
\hline $\begin{array}{l}\text { Chloromonads } \\
\text { (raphidophytes) }\end{array}$ & 2 & 2 & 0 \\
Chrysophytes & 2 & 3 & 1 \\
Cryptophytes & 5 & 5 & 0 \\
Cyanophytes & 2 & 2 & 0 \\
Diatoms: centric & 29 & 43 & 11 \\
Diatoms: pennate & 22 & 25 & 2 \\
Dinoflagellates & 11 & 11 & 0 \\
Euglenophytes & 1 & 1 & 0 \\
Green algae: & & & 1 \\
$\quad$ Chlorophytes & 6 & 7 & 0 \\
$\quad$ Prasinophytes & 4 & 4 & 1 \\
Prymnesiophytes & 8 & 9 & 0 \\
Rhodophytes & 1 & 1 & 16 \\
Total & 93 & 113 & \\
\hline
\end{tabular}

analyses of chlorophyllase activity in a few marine species (Barrett \& Jeffrey 1964, 1971) are included for completeness (see Table 2).

Chlorophyllase enzyme assays. For routine tests of chlorophyllase activity (Table 2) approximately $100 \mathrm{ml}$. cultures were harvested by centrifugation at $2000 \mathrm{~g}$ for 2 to $5 \mathrm{~min}$, the supernatant was discarded, and the algal pellet containing the enzyme resuspended in $2 \mathrm{ml} \mathrm{50 \%} \mathrm{aqueous} \mathrm{acetone} \mathrm{(Barrett} \mathrm{\&} \mathrm{Jeffrey} \mathrm{1971).}$ After 15 min incubation in the dark at $20^{\circ} \mathrm{C}$ the reaction was stopped by adding $9 \mathrm{ml} 100 \%$ acetone (Barrett \& Jeffrey 1964) to give a final concentration $>90 \%$. The extract was cleared by centrifugation, and the pellet re-extracted with $2 \mathrm{ml}$ portions of $90 \%$ acetone until colourless ( 1 or 2 times). The combined supernatants were used for chlorophyllide a analysis (see below). The accuracy of this enzyme assay (expressed as \% chlorophyll conversion) was $\pm 5 \%$.

Effiect of harvesting procedures (filtration and centrifugation) on chlorophyllase activity. About $75 \mathrm{ml}$ culture was diluted with $500 \mathrm{ml}$ filtered seawater. One $250 \mathrm{ml}$ portion was filtered under slight negative pressure (250 to $380 \mathrm{~mm} \mathrm{Hg}$ ) onto Whatman GF/C filters. This step took 1 to $2 \mathrm{~min}$, and the filters contain- 
Table 2. Chlorophyllase activity in unicellular marine algae from 10 classes. Cells were incubated in $50 \%$ acetone for 15 min at $20^{\circ} \mathrm{C}$ and \% conversion determined by chromatography and spectrophotometry

\begin{tabular}{|c|c|c|}
\hline Species & Isolator, source or deposition & $\begin{array}{c}\text { Chlorophyllide a formed as } \\
\% \text { of total chlorophyll a }\end{array}$ \\
\hline \multicolumn{3}{|l|}{ Bacillariophyceae } \\
\hline \multicolumn{3}{|l|}{ Pennales } \\
\hline Amphiprora hyalina Eul. ex Van Heurck & J. B. Jordan, FCRG 70, CS-28 & 5 \\
\hline Amphiprora sp. & J. C. Eyles (PH), CS-11 & 0 \\
\hline Amphora sp. & J. C. Eyles (PH), CS-10C & 5 \\
\hline \multirow[t]{3}{*}{ Asterionella glacialis Castr. } & BR. Grant (PH), CS-15 & 95 \\
\hline & J. L. Stauber (PH), CS-90C & 36 \\
\hline & J. L. Stauber $(\mathrm{PH}), \mathrm{CS}-135$ & 73 \\
\hline \multicolumn{3}{|l|}{ Cylindrotheca closterium var. californica } \\
\hline (Meres.) Reim. \& Lewin & G. F. Humphrey (PH), CS-1c & $5 \cdots$ \\
\hline \multirow[t]{2}{*}{ Cylindrotheca closterium Reim. \& Lewin } & T. J. Smayda, FCRG & 0 \\
\hline & J. L. Stauber, Coral Sea, CS-107 & 0 \\
\hline Cylindrotheca fusiformis Reim. \& Lewin & Halifax, CS-13c & $20 ; 50^{\cdots}$ \\
\hline Delphineis sp. & J. C. Eyles (PH), CS-12 & 96 \\
\hline Grammatophora oceanica Ehrenb. & D. Frood (PP), CS-84 & 100 \\
\hline Navicula sp. & J. L. Stauber, Coral Sea, CS-112 & 1 \\
\hline Navicula sp. & J. C. Eyles (PH), CS-46c & $95^{*} \cdot$ \\
\hline Nitzschia frustulum (Kütz.) Grun. & J. L. Stauber, Coral Sea, CS-115 & 30 \\
\hline Nitzschia frustulum var. perminuta Grun. & L. de Phillipa, Georges R. (NSW) CS-60c & 5 \\
\hline Nitzschia fraudulenta Cleve & J. L. Stauber, Port Hacking, CS-101 & 65 \\
\hline Nitzschia seriata Cleve & J. B. Jordan, FCRG 52 & 5 \\
\hline Nitzschia cf. bilobata W. Smith & J. C. Eyles (PH), CS-47 & 0 \\
\hline Nitzschia sp. & J. L. Stauber, Coral Sea, CS-105 & 95 \\
\hline Nitzschia sp. & M. Wootton (PH), CS-5C & 0 \\
\hline Nitzschia sp. & J. L. Stauber, Coral Sea, CS-106 & 30 \\
\hline Phaeodactylum tricornutum Bohl. & Plymouth, $1052 / 1$, CS-29c & $100^{\cdots}$ \\
\hline Pleurosigma delicatulum W. Smith & D. Frood (PP), CS-83 & 9 \\
\hline Thalassionema nitzschioides Grunow & J. C. Eyles (PH), CS-61 & 75 \\
\hline \multicolumn{3}{|l|}{ Centrales } \\
\hline Chaetoceros affinis Lauder & J. C. Eyles (PH), CS-78 & 100 \\
\hline Chaetoceros calcitrans (Paulsen) Takano & Cambridge LB 1001/1, CS-55 & 1 \\
\hline \multirow[t]{2}{*}{ Chaetoceros didymus Ehr. } & B. R. Grant $(\mathrm{PH}), \mathrm{CS}-2$ & $0 \cdots ; 12$ \\
\hline & T J. Smayda, FCRG & 50 \\
\hline Chaetoceros difficile Cleve & J. C. Eyles (PH), CS-8 & 100 \\
\hline Chaetoceros cf. mitra (Bāil.) Cleve & J. C. Eyles ((PH), CS-70 & 0 \\
\hline Chaetoceros cf. radians Shütt & J. C. Eyles (PH), CS-68 & 5 \\
\hline Chaetoceros sp. & J. L. Stauber, Coral Sea, CS-119 & 100 \\
\hline Chaetoceros sp. & N. Central Pacific Gyre, FCRG-56 & 90 \\
\hline Coscinodiscus $\mathrm{sp}$ & J. L. Stauber (NW Shelf), CS-150 & 0 \\
\hline Detonula pumila Schütt & J. C. Eyles (PH), CS-72 & 57 \\
\hline \multicolumn{3}{|l|}{ Ditylum brightwellii ( $\mathrm{T}$. West) } \\
\hline \multirow[t]{3}{*}{ Grun. ex van Heurck } & J. C. Eyles (PH), CS-74 & 75 \\
\hline & J. L. Stauber $(\mathrm{PH}), \mathrm{CS}-131$ & 48 \\
\hline & J. B. Jordan, FCRG-64 & 0 \\
\hline \multicolumn{3}{|l|}{ Minutocellus polymorphus (Hargr. \& } \\
\hline Guillard) Hasle, Von Stosch \& Syvertsen & J. C. Eyles $(\mathrm{PH}), \mathrm{CS}-3 \mathrm{C}$ & 10 \\
\hline Eucampia zodiacus Ehr. & J. C. Eyles $(\mathrm{PH}), \mathrm{CS}-71$ & 45 \\
\hline \multirow[t]{2}{*}{ Lauderia annulata Cleve } & J. B. Jordan, FCRG-14, CS-30 & 50 \\
\hline & J. B. Jordan, FCRG-14 & 10 \\
\hline Lithodesmium undulatum Ehr. & J. B. Jordan, FCRG-25 & 100 \\
\hline \multirow{2}{*}{\multicolumn{3}{|c|}{$\begin{array}{l}\text { Odontella aunta (Lyngb.) de Breb. } \\
\text { Odontella mobiliensis (Bail.) }\end{array}$}} \\
\hline & & \\
\hline \multirow[t]{2}{*}{ Grun. ex Van Heurck } & D. Frood, Great Barrier Reef, CS-82 & 0 \\
\hline & J. L. Stauber (PH), CS-133 & 22 \\
\hline Odontella regia (Schulze) Simonsen & J. C. Eyles (PH), CS-65 & 0 \\
\hline Rhizosolenia fragilissima Berg. & FCRG & 0 \\
\hline \multirow[t]{2}{*}{ Rhizosolenia setigera Brightw. } & D. Frood (PP), CS-62 & 20 \\
\hline & J. L. Stauber (NW Shelf), CS-147 & 20 \\
\hline
\end{tabular}


Table 2 (continued)

\begin{tabular}{|c|c|c|}
\hline Species & Isolator, source or deposition ${ }^{\circ}$ & $\begin{array}{c}\text { Chlorophyllide a formed as } \\
\% \text { of total chlorophyll a }\end{array}$ \\
\hline \multicolumn{3}{|l|}{ Bacillariophyceae (continued) } \\
\hline \multirow[t]{3}{*}{ Skeletonema costatum (Grev.) Cleve } & M. Wootten (PH), CS-6 & $80^{\circ} ; 100^{\cdots}$ \\
\hline & J. C. Eyles (PH), CS-76 & 100 \\
\hline & CCMP, Boothbay Harbour, USA, CS-181 & 100 \\
\hline \multirow[t]{2}{*}{ Stephanopyxis turris (Grev.) Ralfs in Pritch } & L. Provasoli, FCRG, CS-31 & 50 \\
\hline & J. L. Stauber $(\mathrm{PH}), \mathrm{CS}-100$ & 44 \\
\hline \multirow[t]{2}{*}{ Streptotheca tamesis Shrubs } & J. C. Eyles (PH), CS-81 & 100 \\
\hline & J. L. Stauber (PH), CS-129 & 46 \\
\hline \multirow[t]{2}{*}{ Thalassiosira eccentrica (Ehr.) Cleve } & B. R. Grant (PP), CS-17 & 0 \\
\hline & J. L. Stauber (NW Shelf), CS-148 & 0 \\
\hline Thalassiosira stellaris Hasle \& Guillard & S. McGill (PP), CS-16 & 5 \\
\hline \multirow[t]{2}{*}{ Thalassiosira pseudonana Hasle \& Heimd. } & R. Swan, Perth, CS- 20 c & 3 \\
\hline & R. Guillard (Long Island) CS-173 & 0 \\
\hline Thalassiosira oceanica Hasle & J. C. Eyles $(\mathrm{PH}), \mathrm{CS}-67$ & 3 \\
\hline \multirow[t]{3}{*}{ Thalassiosira rotula Meun. } & J. Jordan, FCRG-10, CS-32 & 10 \\
\hline & J. C. Eyles (PH), CS-77 & 6 \\
\hline & FCRG & 5 \\
\hline Thalassiosira sp. & Origin unknown & $31 \cdots$ \\
\hline \multicolumn{3}{|l|}{ Dinophyceae } \\
\hline Amphidinium carterae Hulb. & Halifax, CS-21 & $0^{\cdots}$ \\
\hline Amphidinium klebsii Kof. \& Swez. & Cambridge $1102 / 3, \mathrm{CS}-33$ & 0 \\
\hline Amphidinium hoefleri Schiller \& Diskus & FCRG & 0 \\
\hline Gymnodinium simplex (Lohm.) Kof. \& Swez. & Origin unknown & $0^{\cdots}$ \\
\hline Gymnodinium sanguineum Hirasaka & F. T. Haxo, PY-14, CS-35 & 0 \\
\hline Gymnodinium sp. & Plymouth $(1117 / 2)$, CS-36 & 2 \\
\hline Gyrodinium resplendens Hulb. & FCRG & 0 \\
\hline Peridinium balticum (Levan.) Lemm. & F. T. Haxo, La Jolla, PY-14, CS-38 & 1 \\
\hline Kryptoperidinium foliaceum (Stein) Lindeman & UTEX 1688, CS-37 & 1 \\
\hline Prorocentrum gracile Schütt & D. Frood, CS-80 & 0 \\
\hline Prorocentrum micans Ehr. & W. H. Thomas, La Jolla, FCRG, CS-27 & 0 \\
\hline \multicolumn{3}{|l|}{ Raphidophyceae } \\
\hline Fibrocapsa japonica Toriumi \& Takano & J. B. Jordan, Pt. Loma, FCRG-51, CS-34 & 7 \\
\hline Heterosigma akashiwo (Hada) Hada & M. Parke, CS-39 & $0 \cdots$ \\
\hline \multicolumn{3}{|l|}{ Chrysophyceae } \\
\hline \multirow[t]{2}{*}{ Pelagococcus subviridis Norris } & B. C. Booth, North Atlantic, CS-58 & $100^{\cdots} \cdot$ \\
\hline & J. L. Stauber (PH), CS-99 & 0 \\
\hline Sphaleromantis sp. & Origin unknown & $100^{*}$ \\
\hline \multicolumn{3}{|l|}{ Prymnesiophyceae } \\
\hline Cricosphaera carterae (Braar. \& Fag.) Braarud & L. Provasoli, CS-40 & 0 \\
\hline Emiliania huxleyi (Lohm.) May \& Mohl. & $\begin{array}{l}\text { R. Guillard, Sargasso Sea, } \\
\text { W. H. Thomas BT6, CS-57 }\end{array}$ & 0 \\
\hline Isochrysis galbana Parke & Halifax, Canada, CS-22 & $0^{*}$ \\
\hline Pavlova Iutheri (Droop) Green & Halifax, Canada, CS-23 & $5 \cdots$ \\
\hline Pavlova sp. & D. Frood (PP), CS-63 & 15 \\
\hline Pavlova sp. & $\begin{array}{l}\text { R. Guillard, Sargasso Sea, } \\
\text { Woods Hole, CS-50 }\end{array}$ & 20 \\
\hline Pavlova sp. & R. Guillard, Sargasso Sea, CS-49 & 18 \\
\hline \multirow[t]{2}{*}{ Phaeocystis pouchetii (Hariot) Lagerheim } & J. L. Stauber (PH), CS-165 & 8 \\
\hline & S. I. Blackburn (Southern Ocean), CS-188 & 40 \\
\hline \multicolumn{3}{|l|}{ Cryptophyceae } \\
\hline Chroomonas sp. & Port Hacking, CS-24 & $5 \cdots$ \\
\hline Cryptomonas maculata Butcher & L. Borowitzka, Dee Why, Roche, CS-85 & 0 \\
\hline Unidentified crypto F 5a & Woods Hole & $0 \cdots$ \\
\hline Unidentified crypto $3 c$ & Woods Hole & $0 \cdots$ \\
\hline STX-157 (Chroomonas sp.?) & K. C. Haines, St Croix, CS -48 & 0 \\
\hline \multicolumn{3}{|l|}{ Rhodophyceae } \\
\hline Porphyridium purpureum (Bor.) Drev \& Ross & Halifax, Canada, CS-25c & $0^{\cdots}$ \\
\hline
\end{tabular}


Table 2 (continued)

\begin{tabular}{|c|c|c|}
\hline Species & Isolator, source or deposition * & $\begin{array}{l}\text { Chlorophyllide a formed as } \\
\% \text { of total chlorophyll a }\end{array}$ \\
\hline \multicolumn{3}{|l|}{ Chlorophyceae } \\
\hline Chlorella stigmatophora Butch. & Origin unknown & $0 \cdots$ \\
\hline \multirow[t]{2}{*}{ Dunaliella tertiolecta Butch. } & Halifax, Canada, CS-14c & $79 \cdots$ \\
\hline & CCMP, CS- 175 & 12 \\
\hline Nannochloris atomus Butch. & Origin unknown & $0 \cdots$ \\
\hline \multicolumn{3}{|l|}{ Prasinophyceae } \\
\hline \multicolumn{3}{|l|}{ Micromonas pusilla (Butcher) } \\
\hline Manton and Parke & UTEX LB 991, CS-86 & 0 \\
\hline Tetraselmis chui Butch. & G. W. Griffith, Galverston, CS-26 & 1 \\
\hline Tetraselmis suecica (Kyl). (Butch) & Cambrigde $66 / 4, \operatorname{CS}-56$ & $0^{*}$ \\
\hline Unidentified prasinophyte, omega 48 & CCMP, omega 48-23AX & 1 \\
\hline \multicolumn{3}{|l|}{ Cynanophyceae } \\
\hline Oscillatoria cf. woronichinii & T. J. Smayda, Mass., FCRG SM-24, CS-52 & 20 \\
\hline \multicolumn{3}{|c|}{$\begin{array}{l}\text { - Code: CS = CSIRO Culture Collection number; Cambridge = The Culture Collection of Algae and Protozoa, Cambridge; } \\
\text { FCRG = Food Chain Research Group, Scripps Oceanography, USA; Halifax = Halifax Regional Laboratory, Nova Scotia, } \\
\text { Canada; Mass. = Massachusetts, USA; PH = Port Hacking isolate, Australia; PP = Port Phillip Bay isolate, Australia; } \\
\text { Plymouth = The Marine Laboratory, Plymouth, UK; Syd. Uni. = Sydney University, Australia; UNSW = University of New } \\
\text { South Wales, Australia; UTEX = Culture Collection of Algae at the University of Texas, USA; Woods Hole = Woods Hole }\end{array}$} \\
\hline \multicolumn{3}{|c|}{$\begin{array}{l}\text { Oceanographic Institution, USA (now CCMP, Bigelow Oceanographic Laboratory) } \\
\cdots \text { Barrett \& Jeffrey 1964, } 1971\end{array}$} \\
\hline
\end{tabular}

ing the algae were then placed immediately in centrifuge tubes containing $100 \%$ acetone to inactivate the chlorophyllase. The other $250 \mathrm{ml}$ portion was harvested by gentle centrifugation ( $2000 \mathrm{~g}$ for $5 \mathrm{~min}$ ), and the cell pellet immediately extracted with $100 \%$ acetone. The extracts were then assayed for chlorophyll a and chlorophyllide a by chromatography and spectrophotometry.

Assay of chlorophyllide a by thin-layer chromatography. The pigments were transferred from acetone to diethyl ether (peroxide-free) for chromatographic analysis, by adding an equal amount of diethyl ether to the acetone extract and gently mixing with 10 volumes $5 \% \mathrm{NaCl}$ solution. The ether hyperphase was collected, concentrated under a stream of nitrogen, and chromatographed on thin layers of specially purified cellulose (Jeffrey 1981), using a solvent system of $2.5 \% n$-propanol in petroleum ether (ligroine [USA]; 60 to $80^{\circ} \mathrm{C}$ fraction). After development in one dimension (approximately $5 \mathrm{~min} ;$ Fig. 1) the chlorophyll a $\left(R_{f}=0.75\right)$ and chlorophyllide $a\left(R_{f}=0.28\right)$ zones were collected and eluted quantitatively with $100 \%$ acetone. Extinctions were read at $664 \mathrm{~nm}$ in a Unicam SP500 or Cary Model 17 spectrophotometer. Chromatography plus elution gave recoveries of 90 to $92 \%$ (Jeffrey 1981).

Assay of chlorophyllide a formation by solvent partition. A rapid method for the assay of chlorophyllide a was frequently used, after the formation of chloro- phyllide $a$ had been confirmed by chromatography. Four $\mathrm{ml}$ hexane $\left(68\right.$ to $70^{\circ} \mathrm{C}$ ) and $1 \mathrm{ml} 0.05 \% \mathrm{NaCl}$ were added to $3 \mathrm{ml}$ of the original $90 \%$ acetone extract in a glass-stoppered $10 \mathrm{ml}$ graduated centrifuge tube, which was gently mixed by inverting 20 times (cf. Parsons 1963). Chlorophyll a migrated to the hexane hyperphase, and chlorophyllide a was retained in the aqueous hypophase. The relative amount of chlorophyllide $a$ in the pigment mixture was then estimated from the difference in extinction at $664 \mathrm{~nm}$ of the original acetone extract and the hexane fraction. A correction was made for the larger volume of the hexane layer ( $4 \mathrm{ml}$, compared to $3 \mathrm{ml}$ acetone) and for the slightly higher extinction coefficient of chlorophyll a in the hexane/acetone mixture compared to $90 \%$ aqueous acetone as solvent (Whitney \& Darley 1979). Provided the chlorophyll content of the original acetone extract was not too low $\left(>0.2 \mu \mathrm{g} \mathrm{ml}^{-1}\right)$ the method agreed with the results obtained by chromatography to within $\pm 5 \%$.

Zero time controls. Controls with species containing highly active chlorophyllase were difficult to perform in the absence of a good enzyme inhibitor which could be added to the culture before sample preparation commenced. However, in certain cultures of pennate diatoms which adhered to the culture walls, the culture medium was decanted, and the cells extracted either in $100 \%$ acetone (without filtration or centrifugation), or frozen in ether-dry ice mixtures at $-70^{\circ} \mathrm{C}$, and then 


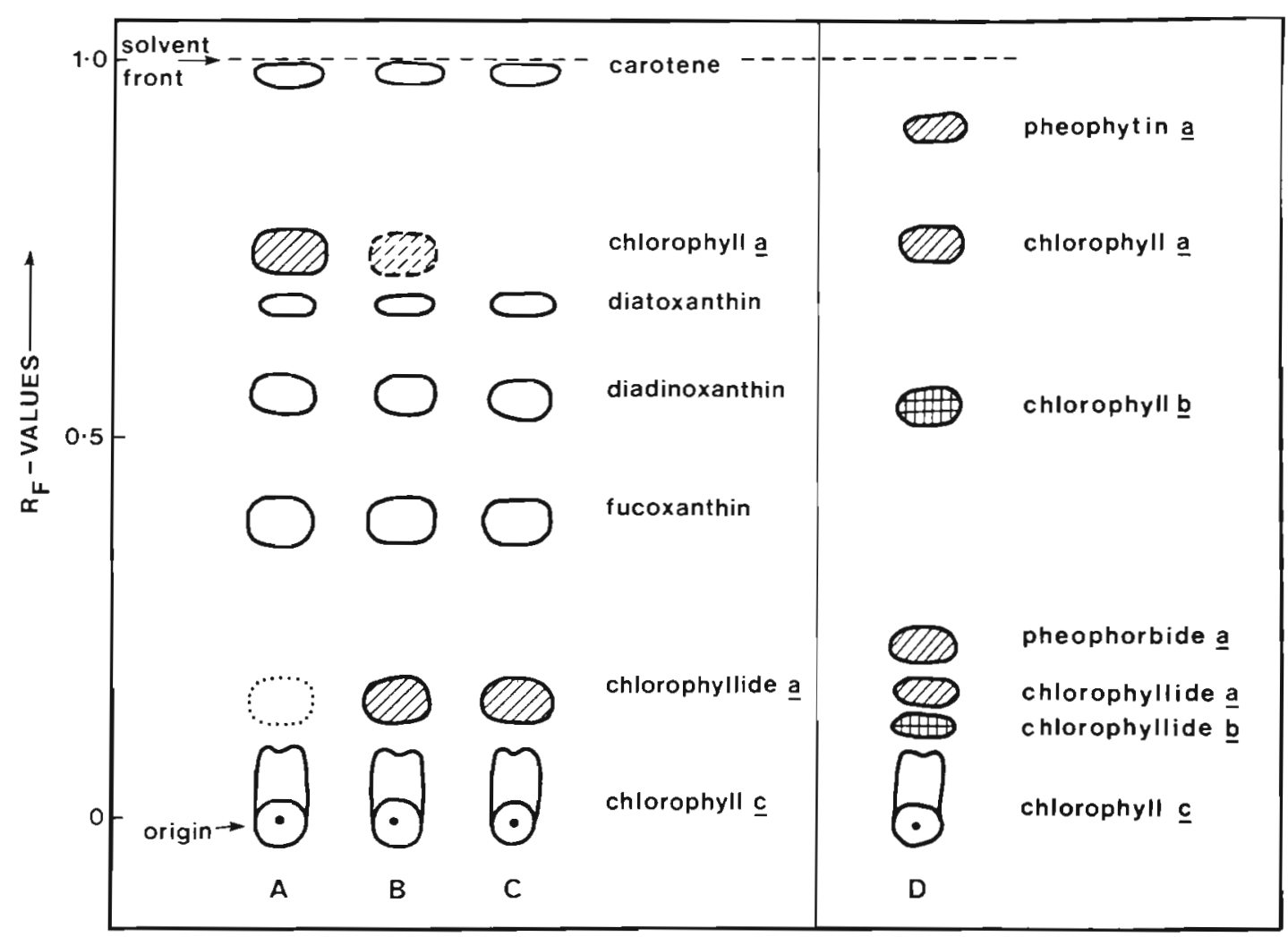

Fig. 1. Skeletonema costatum. Cellulose thin-layer chromatogram of pigments from a $9 \mathrm{~d}$ old culture. Incubation conditions: (A) no incubation, cells harvested by low-speed centrifugation $(2000 \mathrm{rpm})$ and extracted with $100 \%$ acetone; (B) no incubation, cells harvested by filtration $(250 \mathrm{~mm} \mathrm{Hg}$ ) and extracted with $100 \%$ acetone; (C) Cells incubated in $50 \%$ acetone for $15 \mathrm{~min}$, reaction stopped with $90 \%$ acetone. Chlorophyllide a accounted for 3,74 and $100 \%$ of the total chlorophyll $a$, in Treatments 1,2 and 3 respectively. (D) Standard chromatogram showing position of chlorophylls and derivatives. Solvent system $2.5 \% n$-propanol in petroleum ether $\left(60\right.$ to $80^{\circ} \mathrm{C}$ fraction)

extracted in cold $100 \%$ acetone. In the case of Cylindrotheca fusiformis (CS-13c), Navicula sp. (CS-46c) and Dunaliella tertiolecta (CS-14c) no chlorophyllide a was present; traces of chlorophyllide a were present in Phaeodactylum tricornutum (CS-29c) and Skeletonema costatum (CS-6), but in Pelagococcus subviridis (CS-58) $60 \%$ of the chlorophyll a was in the form of chlorophyllide a (Lewin et al. 1977) following the above procedures.

\section{RESULTS}

\section{Chlorophyllase activity in algal species}

Chlorophyllase activity in the 88 marine species tested are listed in Table 2, which includes for completeness results of 21 species previously examined (Barrett \& Jeffrey 1964, 1971). Results of the 5 freshwater species (3 chlorophytes, 1 euglenoid and 1 cyanophyte) are given in Table 3 .

The pennate and centric diatoms tested showed the highest chlorophyllase activity (Table 4). Thirteen out of 43 centric diatom isolates and 10 out of 25 pennate diatom isolates showed greater than $50 \%$ conversion of chlorophyll a to chlorophyllide a under the test conditions, while a number of other diatoms showed less but significant conversion (11 to $50 \%$ ). In contrast, only 3 out of 11 dinoflagellates tested showed any chlorophyllase activity, and this was always less than $10 \%$ conversion.

Low or negligible activity occurred in most of the prymnesiophytes, cryptophytes, prasinophytes, chloromonads, cyanophytes, the euglenoid and the rhodophyte. However, 2 out of 3 chrysophyte isolates showed high activity ( $>50 \%$ conversion) and 5 out of 7 chlorophyte isolates (marine and freshwater) showed from 10 to $>50 \%$ conversion.

Species with high chlorophyllase activity $(>50 \%$ conversion under test conditions) are listed in Table 5. The greatest activity occurred in diatoms commonly found in bloom situations: the pennate diatoms Asterionella glacialis, Cylindrotheca fusiformis, Delphineis sp., Grammatophora oceanica, Navicula sp., Nitzschia (2. spp.), Phaeodactylum tricornutum and 
Table 3. Chlorophyllase activity in unicellular freshwater algae. Analyses as for Table 2

\begin{tabular}{|c|c|c|}
\hline Species & $\begin{array}{l}\text { Isolator, source or } \\
\text { deposition }\end{array}$ & $\begin{array}{l}\text { Chlorophyllide a formed as } \\
\% \text { of total chlorophyl } a\end{array}$ \\
\hline \multicolumn{3}{|l|}{ Chlorophyceae } \\
\hline Chlamydomonas reinhardii Dang. & Syd. Uni. $137 \mathrm{C}+, \mathrm{CS}-51$ & 47 \\
\hline Chlorella pyrenoidosa Chick & Cambridge (211/8?), CS-41 & 15 \\
\hline Chlorella vulgaris Beijer. & Cambridge (211/11?), CS- 42 & 15 \\
\hline \multicolumn{3}{|l|}{ Euglenophyceae } \\
\hline Euglena gracilis Klebs & UNSW Strain 'Z', CS-66 & 10 \\
\hline \multicolumn{3}{|l|}{ Cyanophyceae } \\
\hline Anabaena cylindrica Lemm. & N. Weare, FCRG B-1, CS-53 & 7 \\
\hline - Code as in Table 1 & & \\
\hline
\end{tabular}

Table 4. Summary of chlorophyllase activity in classes of unicellular algae (marine and freshwater)

\begin{tabular}{|c|c|c|c|c|c|c|}
\hline \multirow[t]{2}{*}{ Algal class } & \multirow[t]{2}{*}{$\begin{array}{c}\text { No. of isolates } \\
\text { tested }\end{array}$} & \multicolumn{5}{|c|}{$\begin{array}{l}\text { No. of isolates showing the listed } \% \text { conversion } \\
\text { chlorophyll a to chlorophyllide a under test conditions }\end{array}$} \\
\hline & & $0 \%$ & $1-10 \%$ & $11-20 \%$ & $21-50 \%$ & $>50 \%$ \\
\hline Chloromonads (raphidophytes) & 2 & 1 & 1 & & & \\
\hline Chrysophytes & 3 & 1 & & & & 2 \\
\hline Cryptophytes & 5 & 4 & 1 & & & \\
\hline Cyanophyte (freshwater) & 1 & & 1 & & & \\
\hline Cyanophyte (marine) & 1 & & 1 & & & \\
\hline Diatoms: centric & 43 & 8 & 10 & 3 & 9 & 13 \\
\hline Diatoms: pennate & 25 & 5 & 7 & 0 & 3 & 10 \\
\hline Dinoflagellates & 11 & 8 & 3 & & & \\
\hline Euglenophyte (freshwater) & 1 & & 1 & & & \\
\hline \multicolumn{7}{|l|}{ Green algae: } \\
\hline Chlorophytes (freshwater) & 3 & & & 2 & 1 & \\
\hline Chlorophytes (marine) & 4 & 2 & & 1 & & 1 \\
\hline Prasinophytes & 4 & 3 & 1 & & & \\
\hline Prymnesiophytes & 9 & 3 & 2 & 3 & 1 & \\
\hline Rhodophyte & 1 & 1 & & & & \\
\hline Total & 113 & 36 & 28 & 9 & 14 & 26 \\
\hline
\end{tabular}

Thalassionema nitzschioides, and the centric diatoms Chaetoceros (5 spp.), Detonula pumila, Ditylum brightwellii, Eucampia zodiacus, Lithodesmium undulatum, Skeletonema costatum, Stephanopyxis turis and Streptotheca tamesis.

Strain-specific differences in chlorophyllase activity were found in 6 out of 13 diatoms, 1 chrysophyte, 1 prymnesiophyte and 1 chlorophyte (Table 6). Accepting a maximum analytical error of $\pm 10 \%$, significant strain-specific differences were observed in Asterionella glacialis, Chaetoceros didymus, Ditylum brightwellii, Lauderia annulata, Odontella mobiliensis, Streptotheca tamesis, Pelagococcus subviridis, Phaeocystis pouchetii and Dunaliella tertiolecta. Strain differences were negligible in Cylindrotheca closterium, Rhizosolenia setigera, Skeletonema costatum (all strains highly active), Stephanopyxis turris, Thalassiosira eccentrica, T. pseudonana and T. rotula.

\section{Effect of harvesting procedures on chlorophyllase activity}

The effects of gentle centrifugation and filtration on the stability of chlorophyll a are compared in Table 7 . Both young (10 d) and old (5 wk) cultures of 10 species known to contain the enzyme were studied.

Centrifugation caused little or no formation of chlorophyllide $a$ in 8 out of 10 young cultures, but in 2 species (Ditylum brightwellii and Chaetoceros difficile), centrifugation caused 18 and $26 \%$ conversion of chlorophyll a to chlorophyllide a respectively. Old cultures were more susceptible to centrifugal damage than young cultures, 8 out of 10 showing between 13 and $60 \%$ conversion of chlorophyll a to chlorophyllide a. The 2 exceptions were Navicula sp. and Cylindrotheca fusiformis.

Filtration was even more damaging than centrifuga- 
Table 5. List of species with high chlorophyllase activity ( $>50 \%$ conversion of chlorophyll a to chlorophyllide a under test conditions)

\begin{tabular}{|c|c|}
\hline Species & $\begin{array}{l}\text { CSIRO or other } \\
\text { Code No. }\end{array}$ \\
\hline \multicolumn{2}{|l|}{ Bacillariophyceae } \\
\hline \multicolumn{2}{|l|}{ Pennales } \\
\hline Asterionella glacialis & CS-15; CS-135 \\
\hline Cylindrotheca fusiformis & $\mathrm{CS}-13 \mathrm{C}$ \\
\hline Delphineis sp. & CS-12 \\
\hline Grammatophora oceanica & $\mathrm{CS}-84$ \\
\hline Navicula sp. & $\mathrm{CS}-46 \mathrm{c}$ \\
\hline Nitzschia fraudulenta & CS- 101 \\
\hline Nitzschia sp. & $\mathrm{CS}-105$ \\
\hline Phaeodactylum tricornutum & CS-29c \\
\hline Thalassionema nitzschioides & $\mathrm{CS}-61$ \\
\hline \multicolumn{2}{|l|}{ Centrales } \\
\hline Chaetoceros affinis & CS-78 \\
\hline Chaetoceros didymum & FCRG-strain \\
\hline Chaetoceros difficile & $\mathrm{CS}-8$ \\
\hline Chaetoceros sp. & FCRG-56 \\
\hline Chaetoceros sp. & CS-119 \\
\hline Detonula purnila & $\mathrm{CS}-72$ \\
\hline Ditylum brightwellii & CS-74 \\
\hline Eucampia zodiacus & CS-71 \\
\hline Lithodesmium undulatum & FCRG-25 \\
\hline Skeletonema costatum & CS-6; CS-181; CS-76 \\
\hline Stephanopyxis turris & CS-31 \\
\hline Streptotheca tamesis & CS-81 \\
\hline \multicolumn{2}{|l|}{ Chrysophyceae } \\
\hline Pelagococcus subviridis & CS-58 \\
\hline Sphaleromantis sp. & Origin unknown \\
\hline \multicolumn{2}{|l|}{ Chlorophyceae } \\
\hline Chlamydomonas reinhardii & CS-51 \\
\hline Dunaliella tertiolecta & CS-14c \\
\hline
\end{tabular}

tion to both young and old cultures. Four out of 10 young cultures showed substantial conversion of chlorophyll a to chlorophyllide a (40 to $74 \%$ ) after harvesting by filtration (see Fig. 1 for details of Skeletonema costatum). In old cultures, the chloroplast membranes of all species were damaged by filtration, the formation of chlorophyllide a ranging from 13 to $81 \%$.

\section{DISCUSSION}

\section{Distribution of chlorophyllase in unicellular algae}

The present survey indicates that diatoms are the major carriers of the acetone-activated chlorophyllase. In 23 of the 68 diatom isolates tested, over $50 \%$ of the chlorophyll a was converted to chlorophyllide a under the test conditions. The most active diatom species are all common bloom-forming organisms: Asterionella glacialis, Chaetoceros didymus, Detonula pumila, Ditylum brightwellii, Eucampia zodiacus, Lithodes-
Table 6. Strain-specific differences in chlorophyllase activity

\begin{tabular}{|c|c|c|}
\hline Species & Code No. & $\begin{array}{l}\text { \% conversion } \\
\text { chlorophyll a to } \\
\text { chlorophylide a } \\
\text { under test } \\
\text { conditions }\end{array}$ \\
\hline \multicolumn{3}{|l|}{ Bacillariophyceae } \\
\hline \multirow[t]{3}{*}{ Asterionella glacialis } & CS-90C & 36 \\
\hline & CS-135 & 73 \\
\hline & CS-15 & 95 \\
\hline \multirow[t]{2}{*}{ Chaetoceros didymus } & $\mathrm{CS}-2$ & $0 ; 12$ \\
\hline & FCRG & 50 \\
\hline \multirow[t]{2}{*}{ Cylindrotheca closterium } & FCRG & 0 \\
\hline & CS-107 & 0 \\
\hline \multirow[t]{3}{*}{ Ditylum brightwellii } & FCRG & 0 \\
\hline & CS-131 & 48 \\
\hline & $\mathrm{CS}-74$ & 75 \\
\hline \multirow[t]{2}{*}{ Lauderia annulata } & FCRG-14 & 10 \\
\hline & CS-30 & 50 \\
\hline \multirow[t]{2}{*}{ Odontella mobiliensis } & CS-82 & 0 \\
\hline & $\mathrm{CS}-133$ & 22 \\
\hline \multirow[t]{2}{*}{ Rhizosolenia setigera } & CS-62 & 20 \\
\hline & CS -147 & 20 \\
\hline \multirow[t]{3}{*}{ Skeletonema costatum } & CS-6 & $80 ; 100$ \\
\hline & CS-181 & 100 \\
\hline & CS-76 & 100 \\
\hline \multirow[t]{2}{*}{ Stephanopyxis turris } & CS -100 & 44 \\
\hline & CS-31 & 50 \\
\hline \multirow[t]{2}{*}{ Streptotheca tamesis } & CS-129 & 46 \\
\hline & CS-81 & 100 \\
\hline \multirow[t]{2}{*}{ Thalassiosira eccentrica } & CS-17 & 0 \\
\hline & CS-148 & 0 \\
\hline \multirow[t]{2}{*}{ Thalassiosira pseudonana } & $\mathrm{CS}-173$ & 0 \\
\hline & CS-20c & 3 \\
\hline \multirow[t]{3}{*}{ Thalassiosira rotula } & FCRG & 5 \\
\hline & $\mathrm{CS}-77$ & 6 \\
\hline & $\mathrm{CS}-32$ & 10 \\
\hline \multicolumn{3}{|l|}{ Chrysophyceae } \\
\hline Pelagococcus subviridis & CS-99 & 0 \\
\hline \multirow{2}{*}{$\begin{array}{l}\text { Prymnesiophyceae } \\
\text { Phaeocystis pouchetii }\end{array}$} & $\mathrm{CS}-58$ & 100 \\
\hline & CS-165 & 8 \\
\hline \multirow{3}{*}{$\begin{array}{l}\text { Chlorophyceae } \\
\text { Dunaliella tertiolecta }\end{array}$} & CS-188 & 40 \\
\hline & $\mathrm{CS}-175$ & 12 \\
\hline & $\mathrm{CS}-14 \mathrm{C}$ & 79 \\
\hline
\end{tabular}

mium undulatum, Navicula sp., Nitzschia spp., Skeletonema costatum, Stephanophyxis turris, Streptotheca tamesis and Thalassionema nitzschioides. Within the other classes, only 2 green flagellates (Dunaliella tertiolecta and the freshwater Chlamydomonas reinhardir) and 2 chrysophytes (Pelagococcus subviridis [1 strain] and Sphaleromantis sp.) showed high activity. Representatives of 7 other algal classes showed zero or low activity 10 to $10 \%$ conversion of chlorophyll a to chlorophyllide a). These included dinoflagellates, most prymnesiophytes, cryptophytes, prasinophytes, chloromonads, cyanophytes, a euglenophyte and a rhodophyte. 
Table 7. Effect of cell harvesting techniques (centrifugation and filtration) and culture age on chlorophyllase activity in some unicellular marine algae

\begin{tabular}{|c|c|c|c|c|c|}
\hline \multirow[t]{2}{*}{ Algae } & \multirow[t]{2}{*}{ CSIRO Culture No. } & \multicolumn{2}{|c|}{ Young culture (1 wk) } & \multicolumn{2}{|c|}{ Old culture (5 wk) } \\
\hline & & Centrifugation & Filtration & Centrifugation & Filtration \\
\hline Dunaliella tertiolecta & $\mathrm{CS}-14 \mathrm{C}$ & 0 & 6 & 13 & 15 \\
\hline Navicula sp. & CS $-46 c$ & 0 & 0 & 3 & 13 \\
\hline Cylindrotheca fusiformis & $\mathrm{CS}-13 \mathrm{C}$ & 0 & 0 & 0 & 20 \\
\hline Detonula pumila & $\mathrm{CS}-72$ & 0 & 3 & 60 & 50 \\
\hline Stephanopyxis turris & $\mathrm{CS}-31$ & 5 & 0 & 37 & 32 \\
\hline Phaeodactylum tricornutum & $\mathrm{CS}-29 \mathrm{C}$ & 0 & 7 & 13 & 44 \\
\hline Streptotheca tamesis & $\mathrm{CS}-81$ & 8 & 40 & 22 & 81 \\
\hline Skeletonema costatum & $\mathrm{CS}-6$ & 3 & 74 & 40 & 75 \\
\hline Ditylum brightwellii & CS-74 & 18 & 55 & 21 & 49 \\
\hline Chaetoceros difficile & $\mathrm{CS}-8$ & 26 & 70 & 24 & 60 \\
\hline
\end{tabular}

Strain-specific differences in chlorophyllase activity were seen in 6 out of 13 diatom cultures, as well as different isolates of Pelagococcus subviridis (chrysophyte), Phacocystis pouchetii (prymnesiophyte) and Dunaliella tertiolecta (chlorophyte). The differences seen may reflect inherent strain (i.e. genetic) differences, or physiological changes in the cells imposed by the isolation and culture conditions. These observations caution against generalizing from the present work to phytoplankton species in the world ocean, even though the chlorophyllase activity in isolates of other species was similar (Table 6).

\section{Activation of chlorophyllase during harvesting procedures}

The finding in the present work that membranebound chlorophyllase can be activated by cell-harvesting techniques poses a major problem for chlorophyll analysis. In intact cells, chlorophyllase is inactive as a hydrolytic enzyme, since it is bound at sites inaccessible to its chlorophyll substrate (Terpstra 1976). Therefore, gentle centrifugation of young cultures would be expected to cause little damage, and except for 2 very fragile diatoms (Table 7) this was the case. However, in older cultures, which contained a higher proportion of senescent cells, centrifugation caused greater cell damage, and therefore greater conversion of chlorophyll a to chlorophyllide $a$.

Filtration, even at low suction pressures, was more damaging than centrifugation to thylakoid membranes. In young cultures filtration severely damaged thylakoid membranes of some large centric diatoms and led to significant formation of chlorophyllide a, but caused negligible damage to other species. However, in old cultures of all species tested, filtration caused significant thylakoid disorientation, the per- centage conversion of chlorophyll $a$ to chlorophyllide $a$ ranging from 13 to $81 \%$.

\section{Implications for chlorophyll analysis}

Many of the diatoms with high chlorophyllase activity examined in the present work are common bloomforming organisms in coastal waters throughout the world. When harvesting these algae by usual filtration procedures, a considerable part of their chlorophyll a may be converted to chlorophyllide $a$.

If chlorophylls are measured by simple routine spectrophotometric (Jeffrey \& Humphrey 1975) or fluorimetric (Holm-Hansen et al. 1965) methods, which do not distinguish between chlorophyll a and chlorophyllide a, artificially-produced chlorophyllide a would not affect the accuracy of the results, since the visible absorption and fluorescence spectra of chlorophyllide $a$ are identical to those of chlorophyll $a$ and would be measured as such. The presence or absence of the phytol chain does not influence molar absorption coefficients of the chlorophyll molecule (Holt \& Jacobs 1954). However, if the final product of chlorophyllase activity is pheophorbide $a$, as found in tests with cultured Skeletonema costatum (Suzuki \& Fujita 1986), then chlorophyll a could be underestimated by the above methods because of the differences in the pheophorbide a absorption and fluorescence spectra (Lorenzen \& Jeffrey 1980).

Techniques such as phase separation (Whitney \& Darley 1979) can result in serious underestimation of chlorophyll a because the artificially formed chlorophyllide a would be removed from the chlorophyll measurement. Further, TLC (Jeffrey 1981, Hallegraeff \& Jeffrey 1985) and HPLC techniques (Mantoura \& Llewellyn 1983, Wright \& Shearer 1984, Bidigare et al. 1985, Murray et al. 1986), which sepa- 
rate and quantitate chlorophylls and a wide spectrum of chlorophyll derivatives, may be rendered invalid if chlorophyll breakdown products seen on chromatograms are formed during the harvesting and extraction procedures. The present work and that of Suzuki \& Fujita (1986) show that the possibility of artefacts occurring during harvesting procedures is particularly acute when diatoms are present in the samples.

Owens \& Falkowski's (1982) work on chlorophyllase activity in isolated thylakoid preparations supports these conclusions. They found high chlorophyllase activity in thylakoids from several diatoms and minor activity in preparations from several flagellate groups. They also obtained evidence for a 'magnesiumremoval' enzyme in thylakoids of some diatoms. This enzyme detaches magnesium from the chlorophyllide a formed from the chlorophyllase reaction resulting in the production of pheophorbide $a$.

In a study of chlorophyllase in Skeletonema costatum cultures, Suzuki \& Fujita (1986) found, as we did, that both centrifugation and filtration activated the enzyme. They also found some enzyme activity in $100 \%$ acetone, and recommended heat treatment $\left(65^{\circ} \mathrm{C}\right.$ for $2 \mathrm{~min}$ in $100 \%$ acetone) for complete enzyme inactivation. In our study, $100 \%$ acetone, without heat treatment, caused complete enzyme inhibition. Suzuki \& Fujita (1986) also described the formation of both chlorophyllide $a$ and pheophorbide $a$, as end products of enzyme activity. In our study, pheophorbide a was seldom detected. In a related study in our laboratory, pigments in 51 diatom species (Stauber 1984) were analysed by 2 -dimensional TLC after cell harvesting by centrifugation and pigment extraction in $100 \%$ acetone, and traces of pheophorbide a were detected in only 2 species, Nitzschia fraudulenta and a tropical Chaetoceros. The discrepancies in the results of the 2 laboratories may be attributable to differences in the culture conditions used, to strain-specific enzyme differences, and possibly also to activation of the Owens \& Falkowski 'Mg-removal' enzyme in Suzuki \& Fujita's work. The $S$. costatum cultures used by Suzuki \& Fujita were aerated with $0.5 \% \mathrm{CO}_{2}$ in air, under continuous light. This may have caused sufficient acid to accumulate in the cells' vacuoles to form pheophorbide a from chlorophyllide. In our study, non-aerated stationary cultures were grown under 12 : 12 light: dark cycles and the $\mathrm{pH}$ of the growth medium was maintained between 7.9 and 8.5. Possibly our cultured algae resemble some field situations, for in field studies we identified chlorophyllide a but not pheophorbide a as a major chlorophyll degradation product during diatom blooms (Jeffrey 1974, Hallegraeff 1981).

In the $50 \%$ acetone assay test, 36 out of 113 algal isolates tested in our experiments showed no chlorophyllase activity (Table 4). The enzyme may be absent, or it may be less accessible to solvent activation, and therefore does not pose a problem for chlorophyll analysis.

The present work, showing formation of chlorophyllide a during filtration of algal cells, particularly diatoms, cautions against the earlier suggestion (Jeffrey 1974) that chlorophyllide a seen on chromatograms is a marker for senescent diatoms. Until methods are found to inactivate the enzyme during harvesting procedures, chlorophyllide a presently found on chromatograms must be considered a possible artefact. Suzuki \& Fujita (1986) suggested the use of a hypertonic medium in the final stages of filtration to prevent chloroplast damage, but neither they nor we have been able to achieve consistent success with this method. Perhaps the problem will be solved by adding a suitable chlorophyllase inhibitor prior to filtration or centrifugation. p-Cloro-mercuribenzoate, which inhibits chlorophyllase from rye seedlings (Klein \& Vishniac 1961) and Euglena gracilis (Terpstra 1977), but not Ailanthus altissima (McFeeters et al. 1971) or Phaeodactylum tricornutum (Terpstra 1977), might deter artefact formation in some species. However, the general toxicity of this enzyme inhibitor would caution against its use in routine field studies.

HPLC and TLC are now the methods of choice for accurate analysis of all chlorophylls and derivatives in phytoplankton samples. These methods are being used increasingly in oceanography for water-column work (Gieskes \& Kraay 1983a, b, Mantoura \& Llewellyn 1983, Hallegraeff \& Jeffrey 1985, Murray et al. 1986 , Jeffrey \& Hallegraeff in press), sediment-trap experiments (Repeta \& Gagosian 1982) and grazing experiments (Kleppel \& Pieper 1984). The value of increased sensitivity and refinement of separation procedures may be rendered useless if artefact formation during sample preparation is not prevented. Use of $100 \%$ instead of $90 \%$ acetone as extraction solvent should prevent chlorophyllase activity during extraction, although Suzuki \& Fujita (1986) found that 100\% acetone was not sufficient and recommended heat treatment $\left(65^{\circ} \mathrm{C}\right.$ for $\left.2 \mathrm{~min}\right)$ for complete inactivation of their Skeletonema costatum chlorophyllase. Clearly, now that the problem of chlorophyllase activity has been identified as seriously invalidating results of pigment analysis using separation techniques, appropriate procedures must be found to inactivate it during sample preparation and analysis.

Acknowledgements. We thank Mrs J. C. Eyles and Mrs J. L. Stauber (1978-1980) and Dr. S. Blackburn (1986) for expert maintenance of the CSIRO Algal Culture Collection while these studies were carried out, and $\mathrm{Mr} \mathrm{J}$. Jordan for provision of cultures from the FCRG Culture Collection at the Scripps Institution of Oceanography in California in 1973. SWJ also wishes to thank Dr. Paul Nival, Deputy Director. Station 
Zoologique, Villefranche-sur-Mer, France, for providing peaceful visitor facilities (April 1986), that made completion of this manuscript possible. We are also indebted to Dr. Colin Gibbs for valuable comments on the paper.

\section{LITERATURE CITED}

Barrett, J., Jeffrey, S. W. (1964). Chlorophyllase and formation of an atypical chlorophyllide in marine algae. Pl. Physiol. Lancaster 39: 44-47

Barrett, J., Jeffrey, S. W. (1971). A note on the occurrence of chlorophyllase in marine algae. J. exp. mar. Biol. Ecol. 7: 252-262

Beale, S. I. (1984). Biosynthesis of photosynthetic pigments in chloroplast biogenesis. In: Baker, N. R., Barber, J. (ed.) Elsevier Science Publishers, Annsterdam, p. 135-205

Bidigare, R. R., Kennicutt II, M. C., Brooks, J. M. (1985). Rapid determination of chlorophylls and their degradation products by high-performance liquid chromatography. Limnol. Oceanogr. 30: 432-435

Gieskes, W. W. C., Kraay, G. W. (1980). Primary production and phytoplankton pigment measurements in the northern North Sea during FLEX-76. Meteor Forsch.-Ergebnisse A 22: 105-112

Gieskes, W. W. C., Kraay, G. W. (1983a). Unknown chlorophyll a derivatives in the North Sea and the tropical Atlantic Ocean revealed by HPLC analyses. Limnol. Oceanogr. 28: 757-766

Gieskes, W. W. C., Kraay, G. W. (1983b). Dominance of Cryptophyceae during the phytoplankton spring bloom in the central North Sea detected by HPLC analysis of pigments. Mar. Biol. 75: 179-185

Gowen, R. J., Tett, P., Wood, B. J. B. (1983). Changes in the major dihydroporphyrin plankton pigments during the spring bloom of phytoplankton in two Scottish sea lochs. J. mar. biol. Ass. U.K. 63: 27-36

Guillard, R. R. L., Ryther, J. H. (1962). Studies on marine planktonic diatoms. I. Cyclotella nana Hustedt and Detonula confervacea (Cleve) Gran. Can. J. Microbiol. 8: $229-239$

Hallegraeff, G. M. (1981). Seasonal study of phytoplankton pigments and species at a coastal station off Sydney: importance of diatoms and the nanoplankton. Mar. Biol. 61: $107-118$

Hallegraeff, G. M., Jeffrey, S. W. (1985). Description of new chlorophyll a alteration products in marine phytoplankton. Deep Sea Res. 32: 697-705

Holden, M. (1961). The breakdown of chlorophyll by chlorophyllase. Biochem. J. 78: 350-364

Holden, M. (1963). The purification and properties of chlorophyllase. Photochem. Photobiol. 2: 175-180

Holm-Hansen, O., Lorenzen, C. J., Holmes, R. W., Strickland, J. D. H. (1965). Fluorometric determination of chlorophyll. J. Cons. perm. int. Explor. Mer 30: 3-15

Holt, A. S., Jacobs, E. E. (1954). Spectroscopy of plant pigments 1. Ethyl chlorophyllides $a$ and $b$ and their pheophorbides. Am. J. Bot. 41: 710-722

Jeffrey, S. W. (1965). Paper chromatographic separation of pigments in marine phytoplankton. Aust. J. mar. Freshwat. Res. 16: 307-313

Jeffrey, S. W. (1974). Profiles of photosynthetic pigments in the ocean using thin-layer chromatography. Mar. Biol. 26: $101-110$
Jeffrey, S. W. (1979). Cultivating unicellular marine plants. In: CSIRO Fish and Oceanogr., Hobart, A. Rep. 1977-1979, p. $22-43$

Jeffrey, S. W. (1981). An improved thin-layer chromatography technique for marine phytoplankton pigments. Limnol. Oceanogr. 26: 191-197

Jeffrey, S. W., Hallegraeff, G. M. (in press). Phytoplankton pigments, species and light climate in a complex warmcore eddy of the East Australian Current. Deep Sea Res.

Jeffrey, S. W., Humphrey, G. F. (1975). New spectrophotometric equations for determining chlorophylls $a, b, c_{1}$ and $c_{2}$ in higher plants, algae and natural phytoplankton. Biochem. Physiol. Pflanz. 167: 191-194

Klein, A. O., Vishniac, W. (1961). Activity and partial purification of chlorophyllase in aqueous systems. J. biol. Chem. 236: 2544-2547

Kleppel, G. S., Pieper, R. E. (1984). Phytoplankton pigments in the gut contents of planktonic copepods from coastal waters off southern California. Mar. Biol. 78: 193-198

Lewin, J. C., Norris, R., Jeffrey, S. W., Pearson, B. (1977). An abberrant chrysophycean alga Pelagococcus subviridis gen. nov. et sp. nov. from the north Pacific Ocean. J. Phycol. 13: 259-266

Loeblich, A. R. III, Smith, V. E. (1968). Chloroplast pigments of the marine dinoflagellate Gyrodinium resplendens. Lipids 3: 5-13

Lorenzen, C. J., Jeffrey, S. W. (1980). Determination of chlorophyll in seawater. UNESCO Tech. Pap. Mar. Sci. 35: $1-20$

Mantoura, R. F, C., Llewellyn, C. A. (1983). The rapid determination of algal chlorophyll and carotenoid pigments and their breakdown products in natural waters by reverse-phase high-performance liquid chromatography. Analytica chim. Acta 151: 297-314

McFeeters, R. F., Chichester, C. O,, Whitaker, J. R. (1971). Purification and properties of chlorophyllase from Ailanthus altissima (Tree-of-Heaven). Pl. Physiol. 47: 609-618

Murray, A. P., Gibbs, C. F., Longmore, A. R., Flett, D. J. (1986). Determination of chlorophyll in marine waters: intercomparison of a rapid HPLC method with full HPLC, spectrophotometric and fluorometric methods. Mar. Chem. 19: 211-227

Nichols, W. H. (1973). Growth media-freshwater. In: Handbook of phycological methods - culture methods and growth measurements. In: Stein, J. R. (ed.) Cambridge University Press, Cambridge, p. 7-24

Owens, T. G., Falkowski, P. G. (1982). Enzymatic degradation of chlorophyll a by marine phytoplankton in vitro. Phytochemistry 21: 979-984

Parsons, T, R. (1963). A new method for the microdetermination of chlorophyll $c$ in sea water. J. mar. Res. 21: 164-171

Parsons, T. R., Maita, Y., Lalli, C. M. (1984). A manual of chemical and biological methods for seawater analysis. Pergamon Press, Oxford

Patterson, J., Parsons, T. R. (1963). Distribution of chlorophyll $a$ and degradation products in various marine materials. Limnol. Oceanogr. 8: 355-356

Repeta, D. G., Gagosian, R. B. (1982). Carotenoid transformations in coastal marine waters. Nature, Lond. 295: 51-53

Saijo, Y., Kamiya, T. (1973). Occurrence of chlorophyllide a in the sea. In: Takenouti, A. Y., et al. (ed.) Biological oceanography of the northern Pacific Ocean. Idemitsu Shoten, Tokyo, p. 191-197

SCOR-UNESCO (1966). Determination of photosynthetic pigments in seawater. Monographs on Oceanographic Methodology, I. UNESCO, Paris, p. 11-18

Shuman, F. R., Lorenzen, C. J. (1975). Quantitative degra- 
dation of chlorophyll by a marine herbivore. Limnol. Oceanogr. 20: 580-586

Stauber, J. L. (1984). Photosynthetic pigments in marine diatoms. M.Sc. thesis, University of Sydney

Strickland, J. D. H., Parsons, T. R. (1972). A practical handbook of seawater analysis. Bull. Fish. Res. Bd Can. 167

Suzuki, R., Fujita, Y. (1986). Chlorophyll decomposition in Skeletonema costatum: a problem in chlorophyll determination of water samples. Mar. Ecol. Prog. Ser. 28: 81-85

Terpstra, W. (1976). Chlorophyllase and lamellar structure in Phaeodactylum tricornutum. III. Situation of chlorophyllase in pigmented membranes. Z. PflPhysiol. 80: $177-188$

Terpstra, W. (1977). A study of properties and activity of chlorophyllase in photosynthetic membranes. Z. PflPhysiol. 85: 139-146

Terpstra, W., Goedheer, J. C. (1975). Chlorophyllase and lamellar structure in Phaeodactylum tricornutum. I Chlorophyll-chlorophyllide conversion within the lamellae. Z. PflPhysiol. 75: 118-130

Whitney, D. E., Darley, W. M. (1979). A method for the determination of chlorophyll $a$ in samples containing degradation products. Limnol. Oceanogr. 24: 183--186

Wright, S. W., Shearer, G. D. (1984). Rapid extraction and high-performance liquid chromatography of chlorophylls and carotenoids from marine phytoplankton. J. Chromatogr. 294: 281-295

This article was submitted to the editor; it was accepted for printing on November 14, 1986 